\title{
A Happy Memory Now
}

By MRS. O. L. WOLTERS, Tolland, Alberta.

Last summer, although a very wet one here, proved to be an enjoyable one for me. After trying to attract Bluebirds near our dwellings for years, we were richly rewarded. A pair occupied the birdhouse near our gate (last year occupied by Tree Swallows) and another pair nested in a twine box in the binder on the other side of the bush, about 400 yards apart. The young seemed to hatch at the same time, five in binder, four in the bird box.

Early one morning I heard Bluebirds making quite a fuss, and surmising the young had started to fly I looked out and saw mother bird fly over a youngster squatting on the ground and then to the trees. She did this several times to one or two and they finally realized it was time to take to the trees. Later in the day, as I was going out for strawberries, Bluebirds flew up on all sides. How thrilling! Both families were present.

Once, earlier in the spring, during a heavy downpour, I saw a pair of Bluebirds fly across the garden to sticks I had for marking dahlias. They took turns looking over spruce and willows and studying the situation, when all of a sudden one disappeared into a particularly thick spruce. Seconds later the other followed and I knew then where Bluebirds go to keep from getting drenched.

Another morning, after about three days of heavy rain, when the birds must have been trying to keep dry mostly, our yard teemed with bird life. As I stood and watched, sever-

\section{Lost Through Fear}

\section{William Jasper, Struan}

A Brewer's Blackbird was feeding in the pasture just behind the barn, As I came by I noticed the old cat creeping up on the bird. I did not think it necessary to alarm the bird as there was nothing to hide the cat from her. When the cat got within about twelve feet the bird saw him. But instead of flying away, the poor creature just stood there and shook. She was too afraid to move. And the cat just ran in and took her. al Goldfinches were in the Cut-leaved Birch, then a pair of Cedar Waxwings flew in. The mother got a Honeysuckle berry from a near by bush and lovingly dropped it into the youngster's mouth. A "daddy" Robin, hopping along, cocked his head, made a dive and came up with a four-inch earthworm. It picked it once and then stood watching it for awhile, before gobbling it up. Young swallows were lined up on the telephone lead wire, some facing east, some west, in order to take their turns getting insects from $\mathrm{Ma}$ and $\mathrm{Pa}$. A very hungry Bluebird was chirping from the clothes line. I tried to interest him in cottage cheese but am not sure if he got some, although I saw him flying inches from it.

I was watching all this panorama from two windows, so was bound to miss seeing some movements, but could hear the delightful choruses and chirpings of all these birds, with many others including House Wrens, Orioles and Flickers.

All of this is a happy memory now, and something to think about as we observe the Chickadees and a pair each of Downy and Hairy Woodpeckers. One evening I saw a Brown Creeper. I have suet stuffed in a wide crack on a telephone pole, near our house. They seem to enjoy it.

\section{A Hawk in Training}

William E. Jasper, Struan, Sask.

As I was gathering up oat sheaves in the fall, I was interested in watching some Red-tailed Hawks. Three young had been hatched and reared, not far from where I was working. These, with their parents, were watching for the mice that ran from under the stooks when the sheaves were lifted.

I saw one of the old hawks swoop down, catch a mouse and fly up again above one of the young that was flying some seventy-five feet above the ground. From about forty feet above it the mouse was dropped. How the young hawk caught that mouse I do not know, but I do know that it did not get by this keen-eyed child, in training. 